\title{
A THREE-DIMENSIONAL EVALUATION OF THE EFFECTS OF DIFFERENT INCISOR INTRUSION MECHANICS TO THE PERMANENT MAXILLARY FIRST MOLAR TEETH BY USING CONE BEAM COMPUTED TOMOGRAPHY (CBCT)
}

\author{
Farkl Kesici İntrüzyon Mekaniklerinin Daimi Üst Birinci Molar Dişlere Etkilerinin \\ $\ddot{U} c ̧$ Boyutlu Olarak Değerlendirilmesi
}

Fatih KAHRAMAN ${ }^{1}$ Nihat KILIÇ ${ }^{2}$ İlhan Metin DAĞSUYU ${ }^{1}$

\author{
Makale Kodu/Article Code $\quad$ : 318138 \\ Makale Gönderilme Tarihi ：01.06.2017 \\ Kabul Tarihi \\ $: 13.06 .2017$
}

\section{ABSTRACT}

Objective: The present study aims to evaluate the impacts of the upper incisor teeth intrusion in deepbite patients by two different techniques to the permanent maxillary first molar tooth using the three-dimensional cephalometric analysis in the individuals.

Materials and Methods: The population of this study consists of 34 patients with $>4 \mathrm{~mm}$ overbite and $\mathrm{a} \geq 2 \mathrm{~mm}$ gummy smile during post-pubertal period. Patients who underwent intrusion of upper incisor teeth were randomized to receive Connecticut intrusion arch (CTA) or miniscrew anchorage intrusion system (MAIS) to compare the impacts on permanent maxillary first molar teeth. Cone Beam Computed Tomography (CBCT) data obtained before (T1) and after (T2) intrusion were evaluated through three-dimensional (3D) cephalometric analysis. Intragroup assessment of treatment-related variables were performed via "t-test in dependent samples" and intergroup comparisons were assessed by "t-test in independent samples".

Results: In patients who underwent intrusion of upper incisors, permanent maxillary first molar teeth became deviated distally $(1.48 \mathrm{~mm} / 7.63$ degree $)$ only in CTA group, a statistically significant difference was found between two groups $(p<0.05)$. The distance between resistance centers of maxillary first molar teeth was only increased in CTA group $(0.31 \mathrm{~mm})$, which also statistically differed from MAIS group.

Conclusion: CTA and MAIS techniques resulted in similar intrusive effects overall at the end of the treatment. While MAIS is recommended when anchorage from posterior region is not desired in patients with deep overbite, we believe that CTA may serve a suitable treatment alternative where miniscrew technique could not be performed.

Keywords: Deep overbite, intrusion, miniscrew, threedimensional cephalometric analysis
ÖZ

Amaç: Bu çalışmanın amacı, derin örtülü kapanışa sahip bireylerde üst kesici dişlerin farklı tekniklerle intrüzyonunun daimi üst 1 . Molar dişe etkilerinin 3 boyutlu sefalometrik analiz ile karşılaştırılmasıdır.

Materyal ve Metot: Araştırmamıza, postpubertal dönemde, overbite' $1>4 \mathrm{~mm}$. ve dişeti gülümsemesi $\geq 2$ mm. olan toplam 34 hasta dahil edilmiştir. Hastalar rastgele bir şekilde Connecticut intrüzyon arkı (CTA) ile minivida ankrajlı intrüzyon sistemi (MAİS) gruplarına ayrılarak üst kesici dişlerin intrüzyonu gerçekleştirilen bireylerde üst 1 . büyük azılarda ortaya çıkan etkileri değerlendirilmiştir. İntrüzyondan önce (T1) ve sonra (T2) alınan konik ışınlı bilgisayarlı tomografi (KIBT) verileri 3 boyutlu (3D) sefalometrik analizle incelenmiştir. Tedaviye bağlı değişenlerin grup içi değerlendirilmesinde "Bağımlı örneklerde t-testi"; gruplar arasındaki karşılaştırılmasında "Bağımsız örneklerde t-testi" uygulanmıştır.

Bulgular: Üst kesici dişlerin intrüzyonu gerçekleştirilen hastalarda, üst 1. molar dişler yalnızca CTA grubundaki bireylerde distale devrilmiş ( $1.48 \mathrm{~mm} / 7.63$ derece) ve bu durum gruplar arasında istatistiksel olarak önemli bulunmuştur $(\mathrm{p}<0.05)$. Üst birinci molar dişin direnç merkezleri arası mesafe yalnızca CTA grubunda artarken $(0.31 \mathrm{~mm})$, gruplar arasında oluşan değişim istatistiksel olarak önemli çıkmıştır.

Sonuç: Tedavi sonunda CTA veya MAİS teknikleri genel olarak benzer intrüziv etkiler oluşturmuşlardır. Özellikle derin örtülü kapanışa sahip bireylerde posterior bölgeden ankraj alınmak istenmediğinde MAİS prosedürünün kullanılmasını önerilirken, minivida uygulamasının yapılamayacağı bireylerde ise CTA uygulamasının başarılı bir alternatif olacağını düşünmekteyiz.

Anahtar Kelimeler: Derin örtülü kapanış, intrüzyon, minivida, üç boyutlu sefalometrik analiz.

\footnotetext{
${ }^{1}$ Department of Orthodontics, Faculty of Dentistry, Osmangazi University, Eskişehir, Turkey.

${ }^{2}$ Department of Orthodontics, Faculty of Dentistry, University of Atatürk, Erzurum, Turkey.
} 


\section{INTRODUCTION}

Deep anterior overbite is a common orthodontic problem and also can be seen with many malocclusion types. ${ }^{1-3}$ According to clinical and radiological examinations, excessive overbite can be treated either extruding the posterior buccal segments, intrusion of maxillary and mandibular anterior teeth or both. ${ }^{3-7}$ Decision of treatment depends on miscellaneous factors like an optimal incisor position, incisor display, smile line, upper lip length, and vertical dimension. ${ }^{5-7}$ For example, maxillary incisor intrusion is recommended for the patients with normal vertical dimension and gummy smiles $^{8}$ with over-eruption of incisors that produces anterior deep bites in non-growing patients. ${ }^{2}$, 9-13 Traditionally, incisor intrusion performed by anterior bite plate ${ }^{6}$, functional appliances ${ }^{14,15}$, j-hook headgears ${ }^{16}$, reverse curved $\operatorname{arches}^{17}$, step-up/step-down bends ${ }^{10}, 2 \times 4$ appliances like a utility arches ${ }^{18}$ or 3-piece intrusion arches. ${ }^{4}$

In addition to this, extrusion of posterior teeth, retroclination of molars and labial tipping of anterior teeth is generally outcome of these techniques. ${ }^{3}, 8, \quad 19-22$ Clockwise rotation of mandibula forced by lifting of molar teeth within alveolar sockets is an unfavorable feature that increases risk of relapse in adults. ${ }^{4,23,24}$

To eliminate above-mentioned negative aspects of intrusion of incisor teeth, treatment of deep overbite by miniscrew supported bone anchorage has been introduced during the last quarter-century. ${ }^{25,}$, 35 , 48 iniscrews has numerous advantages such as allowing for placement in many intraoral regions; low cost; immediate loading opportunity, and simple placing and removing procedure compared with conventional dental implants. ${ }^{49,50}$ Impacts of various techniques used for intrusion of incisor teeth on skeletal and dentoalveolar structures have been comprehensively evaluated through utilization of cephalometric analyses. ${ }^{4}, 5,8,16,19,21,25-30$ However, to our knowledge, there is no study investigating their effects on posterior teeth by threedimensional cephalometric analysis.

The aim of this study was to investigate the impacts of intrusion of each upper incisor tooth of patients with deep overbite, by either Connecticut intrusion arch (CTA) or miniscrew anchored intrusion system (MAIS), on permanent first molar teeth, by using threedimensional cephalometric analysis.

\section{MATERIAL AND METHODS}

This study was approved by the Medical Scientific Ethics Committee of Atatürk University. Informed consent form was obtained from the patients and parents. Subjects that had been referred to Atatürk University Dentistry Faculty Orthodontics Department for treatment were enrolled to the study.

Inclusion criteria to this prospective clinical study were supra-positioning of upper incisor teeth according to occlusal plane, increased overbite $(>4 \mathrm{~mm}$ ), increased gingival display on posed smile ( $\geq 2 \mathrm{~mm}$ ), increased incisor display at rest $(\geq 3 \mathrm{~mm})$, post-pubertal period, and good periodontal health condition. Patients were excluded from the study if following criteria were present: orthodontic treatment history, any dental abnormality in upper incisor region (malformation, supernumerary tooth, etc.), root abnormality of incisor teeth as detected by radiological examinations (resorption, dilaceration, alveolar crest resorption, and presence of impacted canine teeth extending to upper incisor region).

A total of 36 patients were randomly assigned to two different intrusion technique groups. Group 1 consisted of 18 patients (14 females and 4 males) who underwent maxillary incisor intrusion by Connecticut intrusion arch (CTA), and Group 2 consisted of 18 patients (13 females and 5 males) who underwent maxillary incisor intrusion by miniscrew anchorage (MAIS). Two subjects were further excluded from the study due to lack of oral 
hygiene, yielding a total of 34 patients who completed the study.

No other orthodontic treatment was applied before intrusion of all the patients were completed.

In CTA group, a molar band was placed on upper first molar teeth before leveling, and passive transpalatal arch (TPA) was applied to increase anchorage. For avoiding incisor protrusion during intrusion, $0.017 \times 0.025$-inch long-form CTA was cinched back from molar band, and it was bilaterally tied anteriorly by ligature wires to hooks distal to lateral incisors. A total of $80 \mathrm{~g}$ force was applied onto maxillary incisors, $40 \mathrm{~g}$ in average for each tooth. Force calibration was performed by either increasing or decreasing CTA-exclusive V-bends through intraoral dynamometer (Dentaurum, Ispringen, Germany) at every three weeks. Intrusion of maxillary incisor teeth was terminated in both active intrusion groups when amount of resting displayed incisor reached at esthetic margin or incisal surfaces of incisor teeth were intruded till the level of occlusal plane. ${ }^{13,31}$

In MAIS group, after radiological screening, miniscrews were inserted into the alveolar bone between roots of lateral and canine teeth. Miniscrews, we used in our study were $1.5 \mathrm{~mm}$ in diameter and $6 \mathrm{~mm}$ in length (Absoanchor, Dentos, Daegu, South Korea). One week after insertion, closed coil springs (G\&H 9F NiTi Feather Light Close Coil Spring, Indiana, USA) were placed between miniscrews and anchor twists distal to lateral teeth. Afterwards, $80 \mathrm{~g}$ force was applied, $40 \mathrm{~g}$ in average for each tooth with a follow-up interval of three weeks.

CBCT records of patients were obtained through Cone Beam Volumetric Computed Tomography (NewTom 3G, Verona, Italy) device in Department of Oral and Maxillofacial Radiology of Ataturk University Faculty of Dentistry. Irradiation parameters of the device were $110 \mathrm{kVp}$ with an effective dose of $60 \mu \mathrm{Sv}$ (2007 IRCP) per adult.

Computed tomography data of 34 patients, which had been acquired just before (T1) and after (T2) intrusion, were analyzed in a three-dimensional cephalometric method via Simplant Pro O\&O (Materialise, Leuven, Belgium). In this software, position of the head was calibrated in a way that Frankfurt horizontal plane was parallel to the ground in sagittal section, lower orbital borders were at the same level in coronal section, and median palatine suture was perpendicular to the ground in axial section in 3D model. All cephalometric assessments were performed by the same investigator (FK). Pal 3D cephalometric analysis, developed by Ilhan M. Dagsuyu, was utilized in this study.

Skeletal landmarks regarding 3D cephalometric analysis were indicated at Table 1.

\begin{tabular}{|c|c|}
\hline Skeletal landmark & Definition \\
\hline OrR-OrL & Deepest external point of infraorbital border (double points; right and left) \\
\hline Mid-Orbital & Midpoint of OrR and OrL points \\
\hline (PoR-PoL & Most superior midpoint of external acoustic meatus (double points; right and left) \\
\hline PtR-PtL & $\begin{array}{l}\text { Most inferior midpoint of foramen rotundum it reaches on pterygomaxillary fossa } \\
\text { (double points; right and left) }\end{array}$ \\
\hline $\mathbf{C P}$ & Center point; midpoint of right and left pterygoid points \\
\hline FSR-FSL & Geometrical center of foramen spinosum (double points; right and left) \\
\hline ELSA: & Midpoint of right and left foramen spinosum points \\
\hline ANSR-ANSL & $\begin{array}{l}\text { Most anterior and apical point of hard palate at the sagittal plane (double points; right } \\
\text { and left) }\end{array}$ \\
\hline ANS & Midpoint of ANSR and ANSL \\
\hline PNS & Most posterior and apical point of hard palate at the sagittal plane \\
\hline IFR-IFL & Most external right and left point of incisive foramen (double points; right and left) \\
\hline Incisive foramen & Midpoint of IFR-IFL points \\
\hline U1Cr & Apical point of alveolar crest that is mesial to upper central teeth \\
\hline UR2Cr-UL2Cr & $\begin{array}{l}\text { Apical point of alveolar crest that is between upper lateral and canine teeth (double } \\
\text { points; right and left) }\end{array}$ \\
\hline \multicolumn{2}{|l|}{ Dental Landmarks } \\
\hline UR1-UL1 & Midpoint of incisive border of upper central incisor tooth (double points; right and left) \\
\hline MoR-Mol & $\begin{array}{l}\text { Apical point of mesiobuccal tubercle of upper maxillary first molar tooth (double points; } \\
\text { right and left) }\end{array}$ \\
\hline ApUR1-ApUL1 & Apex of upper central incisor tooth (double points; right and left) \\
\hline ApUR6-ApUL6 & Mesiobuccal apex of upper first molar tooth (double points; right and left) \\
\hline TriUR6-TriUL6 & Midpoint of trifurcation of upper first molar tooth (double points; right and left) \\
\hline $\begin{array}{l}\text { Ur1ResCrestal- } \\
\text { UL1ResCrestal }\end{array}$ & $\begin{array}{l}\text { Point at the proximal } 1 / 3 \text { of the distance that extends from alveolar crest within the tooth } \\
\text { on the long axis of upper incisor teeth to ApUR } 1 \text { point (double points; right and left) }\end{array}$ \\
\hline \multicolumn{2}{|c|}{ Reference Planes Used in Current Study } \\
\hline FH & $\begin{array}{l}\text { Frankfort horizontal plane. Horizontal reference plane passing through right }(\mathrm{PoR}) \text { and } \\
\text { left }(\mathrm{PoL}) \text { porion and MidOrbital points }\end{array}$ \\
\hline PP & Horizontal palatine reference plane passing through ANSR, ANSL, and PNS points \\
\hline VPP & $\begin{array}{l}\text { Vertical palatine reference plane that is perpendicular to palatine plane that passes } \\
\text { through ANSR and ANSL points and crosses it at ANS }\end{array}$ \\
\hline
\end{tabular}

Landmarks and reference lines and planes that were used in the study were based on the 
published studies in the literature. ${ }^{32-34} 3 \mathrm{D}$ cephalometric measurements used in current study indicated at Table 2.

Table 2: 3D cephalometric measurements used in current study.

\begin{tabular}{|c|c|}
\hline Measurement & Definition \\
\hline U1RCrPPOrt: & $\begin{array}{l}\text { Mean of the perpendicular distance that extends from both UR IResCrestal and } \\
\text { ULIResCrestal points to PP reference plane }\end{array}$ \\
\hline U1RCrVPPOrt: & $\begin{array}{l}\text { Mean of the perpendicular distance that extends from both UR IResCrestal and } \\
\text { ULIResCrestal points to VPP reference plane }\end{array}$ \\
\hline MorMol & Shortest distance between MoR and MoL points \\
\hline TriUR6TriUL6 & Shortest distance between TriUR6 and TriUL6 points \\
\hline MoPP & $\begin{array}{l}\text { Mean of the perpendicular distance that extends from both MoR and MoL points to PP } \\
\text { reference plane }\end{array}$ \\
\hline MoVPP: & $\begin{array}{l}\text { Mean of the perpendicular distance that extends from both MoR and MoL points to VPP } \\
\text { reference plane }\end{array}$ \\
\hline TriU6PPOrt: & $\begin{array}{l}\text { Mean of the perpendicular distance that extends from both TriUR6 and TriUL6 points to } \\
\text { PP reference plane }\end{array}$ \\
\hline TriU6VPPOrt: & $\begin{array}{l}\text { Mean of the perpendicular distance that extends from both TriUR6 and TriUL6 points to } \\
\text { VPP reference plane }\end{array}$ \\
\hline U6AngleOrt: & $\begin{array}{l}\text { Mean of the angles formed between PP reference plane and both UR6Axis and UL6Axis } \\
\text { lines }\end{array}$ \\
\hline
\end{tabular}

\section{Statistical Analysis}

Statistical analysis was performed using IBM SPSS Statistics (version 20.0.0 New York, USA) The Kolmogorov-Smirnov test was used to evaluate normality; independent-sample $\mathrm{T}$ test and Mann-Whitney $\mathrm{U}$ test were used to analyze the relationships between parameters in two time-points (T1, T2). All statistical analyses were performed at the 5\% significance level.

All measurements were repeated in 15 randomly selected samples after 10 months by the same investigator (FK). The Houston error analysis ${ }^{35}$ was used to examine the differences between $\mathrm{T} 1$ and $\mathrm{T} 2$ time-points (Houston analysis reports that all measurements are between 0.9710 and 0.9986 coefficients). All landmarks and measurements were found highly repeatable.

\section{RESULTS}

Ages, total duration of intrusion, and mean values (and standard deviations) of the subjects in CTA and MAIS groups before the intrusion were shown in Table 3. While pre-treatment age statistically differed between treatment groups ( $\mathrm{p}<0.05$ ), duration of intrusion of upper incisors did not show a significant difference $(\mathrm{p}>0.05)$.
Table 3: Comparison of chronological ages and duration of intrusion of upper incisors in CTA and MAIS groups.

\begin{tabular}{lcccc}
\hline \multirow{2}{*}{ Parameter } & \multicolumn{2}{c}{ CTA } & \multicolumn{3}{c}{ MAIS } \\
\cline { 2 - 5 } & Mean & St. Deviation & Mean (St. Dev.) & Test \\
\hline $\begin{array}{l}\text { Chronological age } \\
\text { (months) }\end{array}$ & 191.88 & 11.62 & $200.17(11.09)$ & $\mathrm{S}^{*}$ \\
$\begin{array}{l}\text { Duration of intrusion of } \\
\text { upper incisors }\end{array}$ & 3.64 & 0.82 & $3.36(1.25)$ & NS \\
\hline
\end{tabular}

*p<0.05, S: significant; NS: non-significant

\section{D Cephalometric Analysis Findings}

\section{Intergroup Baseline Characteristics}

Baseline characteristics of the groups with comparisons were indicated in Table 4. Study groups did not statistically differ in terms of any pre-treatment parameters.

Table 4: Comparison of baseline characteristics by groups.

\begin{tabular}{lcccc}
\hline \multirow{2}{*}{ Parameter } & \multicolumn{2}{c}{ CTA } & MAIS & \\
\cline { 2 - 5 } MoVPP & Mean & St. Deviation & Mean (St. Dev.) & Test \\
\hline MoPP & 28.72 & 2.31 & $30.60(4.19)$ & NS \\
TriU6VPPOrt & 22.78 & 2.57 & $23.26(2.00)$ & NS \\
TriU6PPOrt & 11.32 & 1.68 & $32.85(3.42)$ & NS \\
U6AngleOrt & 90.42 & 4.51 & $90.11(4.52)$ & NS \\
MorMol & 50.29 & 3.33 & $50.74(2.41)$ & NS \\
TriUR6TriUL6 & 44.13 & 2.75 & $45.56(2.39)$ & NS
\end{tabular}

$* \mathrm{p}<0.05$, S: significant; NS: non-significant

\section{Comparison of Intragroup Parameters Before and After Intrusion}

\section{CTA Group}

CTA group showed significant alterations from baseline (T1 to T2) in MoVPP, U6Angleort, MorMol, TriUR6, and TriUL6 parameters $(p<0.05)$. All other values were found similar (Table 5).

Table 5: Assessment of parameters before and after treatment in CTA group.

\begin{tabular}{lcccc}
\hline \multirow{2}{*}{ Parameter } & \multicolumn{2}{c}{ Before Treatment } & After Treatment & \\
\cline { 2 - 5 } & Mean & St. Deviation & Mean (St. Dev.) & Test \\
\hline MoVPP & 28.72 & 2.31 & $30.20(2.26)$ & $\mathrm{S} *$ \\
MoPP & 22.78 & 2.57 & $22.96(2.43)$ & NS \\
TriU6VPPOrt & 31.39 & 1.68 & $31.27(1.44)$ & NS \\
TriU6PPOrt & 11.32 & 2.48 & $11.49(2.47)$ & NS \\
U6AngleOrt & 90.42 & 4.51 & $82.78(4.66)$ & $\mathrm{S} *$ \\
MorMol & 50.29 & 3.33 & $50.94(2.84)$ & $\mathrm{S} *$ \\
TriUR6TriUL6 & 44.13 & 2.75 & $44.44(2.66)$ & $\mathrm{S} *$
\end{tabular}

${ }^{*} \mathrm{p}<0.05$, S: significant; NS: non-significant 


\section{MAIS Group}

MAIS group did not show any statistically significant difference in terms of any parameter from baseline (T1) to study end (T2), as demonstrated in Table 6.

Table 6: Assessment of parameters before and after treatment in MAIS group.

\begin{tabular}{lcccc}
\hline \multirow{2}{*}{ Parameter } & \multicolumn{2}{c}{ Before Treatment } & After Treatment & \\
\cline { 2 - 5 } MoVPP & Mean & St. Deviation & Mean (St. Dev.) & Test \\
\hline MoPP & 30.60 & 4.19 & $30.60(4.27)$ & NS \\
\hline TriU6VPPOrt & 23.26 & 2.00 & $23.20(2.08)$ & NS \\
\hline TriU6PPOrt & 12.85 & 3.42 & $32.93(3.50)$ & NS \\
\hline U6AngleOrt & 90.11 & 4.52 & $11.96(1.83)$ & NS \\
\hline MorMol & 50.74 & 2.41 & $90.29(4.45)$ & NS \\
TriUR6TriUL6 & 45.56 & 2.39 & $41.02(2.63)$ & NS \\
\hline
\end{tabular}

NS: non-significant

\section{Comparison of Intergroup Parameters Before and After Intrusion}

Comparison of changes from $\mathrm{T} 1$ to $\mathrm{T} 2$ between study groups were presented in Table 7 . While U6AngleOrt was found as elevated in MAIS group, it was decreased in CTA group, where the difference was statistically significant.

Table 7: Intergroup comparison of mean changes after incisor intrusion in CTA and MAIS groups.

\begin{tabular}{lcccc}
\hline \multirow{2}{*}{ Parameter } & \multicolumn{2}{c}{ CTA Group } & MAIS Group & \\
\cline { 2 - 5 } Duration & Mean & St. Deviation & Mean (St. Dev.) & Test \\
MoVPP & 3.64 & 0.83 & $3.36(1.25)$ & NS \\
MoPP & 1.48 & .55 & $.00(.47)$ & S * \\
TriU6VPPOrt & .18 & .60 & $-.06(.41)$ & NS \\
TriU6PPOrt & .12 & .67 & $.08(.41)$ & NS \\
U6AngleOrt & -7.63 & .44 & $-.09(.41)$ & NS \\
MorMol * & .65 & 1.14 & $.18(1.06)$ & $\mathrm{S} *$ \\
TriUR6TriUL6 & .31 & .50 & $.28(.59)$ & NS \\
\hline
\end{tabular}

${ }^{*} \mathrm{p}<0.05$, S: significant; NS: non-significant

- non-normally distributed parameter where MannWhitney-U test was performed.

Despite being significantly increased in CTA group, the distance (MoVPP) between crown of upper first molar teeth (MoR, MoL) and vertical palatal reference plane (VPP) did not alter in MAIS group. This intergroup difference was also found as statistically significant.

While the distance between resistance centers of upper first molar teeth was statistically lengthened in CTA group, it was non-significantly shortened in MAIS group. The difference between the groups was also found as statistically significant. No other parameters were statistically significant between study groups.

Intrusion was achieved on the resistance center of upper central incisor teeth in CTA and MAIS groups (intrusion: CTA/MAIS: $1.46 / 1.78 \mathrm{~mm}$ ), where no difference was detected for the amount of intrusion.

\section{DISCUSSION}

Management of deep overbite consists of three principal approaches, namely extrusion of upper/lower posterior teeth, intrusion of upper/lower incisors, and combination of intrusion and extrusion. 4, 15, 23, 24 In addition, orthognathic surgery may also be preferred for extreme cases. ${ }^{24,36}$

Intrusion performed with either CTA or MAIS has distinctive impacts on upper first molar teeth. Since no anchorage was performed from posterior teeth in MAIS group, no significant alteration was detected in crown or resistance center of molar teeth for either sagittal or vertical direction. Therefore, anchorage was preserved in MAIS group in our study. This is consistent with other studies regarding performance of incisor intrusion via miniscrew anchorage. $5,8,16,37-39$

In CTA group, while $1.48 \mathrm{~mm}$ distal displacement of upper first molar teeth crown was found as statistically significant $(\mathrm{p}<0.001)$, its vertical displacement was not significant ( $p>0.05)$. This is consistent with the finding of Nanda who reported distal bending moment of CTA on the crown of molar tooth during creating the intrusion force. ${ }^{7}$ Also consistent with our results, Senisik et al. reported distal advancement of the crown after incisor intrusion by CTA. ${ }^{30}$

Absence of extrusion in upper first molar teeth in CTA may originate from the ability of 
sufficient anchorage of opposite occlusal forces against low vertical extrusion forces. ${ }^{3,40}$ Moreover, TPA application that increases anchorage may also prevent extrusion. It was reported that extrusion of molar teeth after intrusion of incisors may cause relapses particularly in adults. ${ }^{23}$ This is because extrusion of posterior teeth in adults may affect position of the condylar head by rendering clockwise rotation at lower jaw, which in turn, may influence temporomandibular joint and muscles. On the contrary, temporomandibular joint and its surrounding tissues that had not been adapted may lead to relapses after intrusion treatment by successful remodeling. ${ }^{9}$ Therefore, absence of extrusion in our study may imply a more stable property of our intrusion treatment. Our study is consistent with the vertical effects on molar teeth that was reported by the authors performing intrusion of upper incisor teeth via the other intrusion $\operatorname{arch}^{3}$

Our study is not consistent with the findings of Senisik and Turkkahraman who reported $0.80 \mathrm{~mm}$ and $0.92 \mathrm{~mm}$ extrusion for the crown of upper first molar teeth after intrusion of upper incisor through CTA. ${ }^{30}$ This may arise from lack of either intrusion in lower jaw or preventive measures improving anchorage (TPA, headgear) by the investigators. $^{30}$

We found no significant alteration of resistance center of upper first molar teeth in either sagittal or vertical direction after intrusion of incisor teeth in CTA group. This was inconsistent with those CTA-intrusion studies reporting mesial advancing of molar resistance center by $0.30 \mathrm{~mm}$ at anteroposterior axis. ${ }^{30}$ This dissimilarity may be attributed to absence of anchorage-improving measures at upper jaw or observation of more protrusion in incisors.

In our study, a distal deviation of $7.63^{\circ}$ at the long axis of maxillary first molar in CTA group was statistically significant. It was reported that anchorage from molar teeth by intra-arch intrusion techniques might lead to distal deviation of molar teeth. ${ }^{19}$ Our finding was in line with those of other authors performing intrusion through CTA. ${ }^{29,} 30$ On the other hand, there was no significant change in MAIS group. In fact, studies where miniscrew anchorage incisor intrusion was performed reported no significant alteration in the angle created by the molar tooth and palatal plane, consistent with our findings. ${ }^{8,} 16,39$

\section{Evaluation of Transversal Direction Alterations}

Expansion of the distances between each crowns and resistance centers of respective upper first molar teeth by $0.65 \mathrm{~mm}$ and 0.31 $\mathrm{mm}$, respectively in CTA group was not clinically important, albeit being statistically significant. These increments were parallel to that of Van Steenbergen et al. reporting increased width between molar teeth after only anchoring from upper first molar tooth by segmental arch for the intrusion of upper incisor teeth. ${ }^{19}$

In MAIS group, the distances between each crowns and resistance centers of corresponding molar teeth were not significantly altered. In fact, this is expected since no procedure was done posteriorly. This is consistent with Senisik's finding that showed unaltered distance between crowns of molar teeth after miniscrew anchored intrusion of incisor teeth. ${ }^{37}$ On the contrary, Upadhyay et al., in their study where they closed extraction gaps and performed miniscrew anchored incisor intrusion, reported a $1.83 \mathrm{~mm}$ reduction in the distance between crowns of upper first molar teeth. ${ }^{39} \mathrm{We}$ attribute this discrepancy to the differences of investigators in mechanics and therapeutic strategies they used.

\section{Statistical Comparison of Observed Alterations Between Groups}

Mean differences of changes of resistance centers at sagittal and vertical planes showed 
no differences between groups, which is consistent with those of Senisik \& Turkkahraman and Polat-Ozsoy et al. using miniscrew anchored intrusion system alone or with utility arch, respectively. ${ }^{30,8}$

While upper first molar tooth was deviated distally in CTA group, this was not observed in MAIS group. Yielding a significant difference between groups, this finding is parallel to the reports of Senisik \& Turkkahraman and other authors, utilizing CTA and miniscrew anchorage intrusion systems. $^{30,8}$

In terms of alteration between groups at transverse plane, the distance between resistance centers of upper first molar teeth was increased by about $0.3 \mathrm{~mm}$ in CTA group, whereas it did not change in MAIS group, which was statistically significant. This may be explained by CTA's anchorage from upper first molar and by the possibility that TPA which we used as anchorage-improving measure might be prepared as slightly active during laboratory phase.

Our findings could be accepted as similar to the findings published in the literature overall. We suggest that the differences in intrusion values may result from the variety of techniques used, vector properties of the intrusion force (intensity, direction, application point), total duration of therapy, and diversity of age groups.

\section{CONCLUSIONS}

While the crown of upper first molar teeth were displaced to distal and buccal direction in CTA group, there was no displacement in MAIS group.

While upper first molar crown tipped and displaced distally, there was no alteration in MAIS group.

Though transpalatal arch was used in CTA group, crowns of upper first molar crown were displaced to buccal direction.
We recommend in favor of using MAIS procedure when anchoring from posterior region is not desired especially in patients with deep overbite and CTA may serve as an effective alternative where miniscrew technique could not be performed. Use of MAIS may offer advantages when no impact on posterior relation is desired in incisor intrusion.

\section{REFERENCES}

1. Van Steenbergen E, Burstone CJ, PrahlAndersen B, Aartman IH. Influence of buccal segment size on prevention of side effects from incisor intrusion. Am J Orthod Dentofacial Orthop, 2006; 129:658-665.

2. Lewis P. Correction of deep anterior overbite. A report of three cases. Am J Orthod Dentofacial Orthop, 1987;91:342-345.

3. Weiland FJ, Bantleon H-P, Droschl H. Evaluation of continuous arch and segmented arch leveling techniques in adult patients-a clinical study. Am J Orthod Dentofacial Orthop, 1996;110:647-652.

4. Burstone CR. Deep overbite correction by intrusion. Am J Orthod, 1977;72:1-22.

5. Polat-Özsoy Ö, Arman-Özçırpıcı A, Veziroğlu F. Miniscrews for upper incisor intrusion. Eur J Orthod, 2009;31:412-416.

6. Lindauer SJ, Lewis SM, Shroff B. Overbite Correction and Smile Aesthetics. Semin Orthod, 2005;11:62-66.

7. Nanda R, Marzban R, Kuhlberg A. The Connecticut Intrusion Arch. J Clin Orthod, 1998;32:708-715.

8. Polat-Ozsoy O, Arman-Ozcirpici A, Veziroglu F, Cetinsahin A. Comparison of the intrusive effects of miniscrews and utility arches. Am J Orthod Dentofacial Orthop, 2011;139:526-532.

9. Nanda R. Correction of deep overbite in adults. Dent Clin North Am, 1997;41:67-87. 
10.Nanda R, Kuhlberg A. Management of Deep Overbite Malocclusion. In: Nanda $R$ (eds). Biomechanics and Esthetic Strategies in Clinical Orthodontics, St. Louis, Missouri, Elsevier Saunders, 2005.

11.WR. P, HW. F, DM. S. Contemporary Orhodontics. 5th. ed. St. Louis, Missouri 63043, 2013.

12.Dermaut LR, Vanden Bulcke MM. Evaluation of intrusive mechanics of the type "segmented arch" on a macerated human skull using the laser reflection technique and holographic interferometry. Am J Orthod, 1986;89:251-263.

13.Zachrisson BU. Esthetic Factors Involved in Anterior Tooth Display and the Smile: Vertical Dimension. Journal of Clinical Orthodontics, 1998;32:432-445.

14.Ball JV, Hunt NP. The effect of Andresen, Harvold, and Begg treatment on overbite and molar eruption. Eur J Orthod, 1991;13:53-58.

15.Hans MG, Kishiyama C, Parker SH, Wolf GR, Noachtar R. Cephalometric evaluation of two treatment strategies for deep overbite correction. Angle Orthod, 1994;64:265-274; discussion 275-266.

16.Deguchi $\mathrm{T}$, Murakami $\mathrm{T}$, Kuroda $\mathrm{S}$, Yabuuchi T, Kamioka H, Takano-Yamamoto T. Comparison of the intrusion effects on the maxillary incisors between implant anchorage and J-hook headgear. Am J Orthod Dentofacial Orthop, 2008;133:654-660.

17. Mitchell DL, Stewart WL. Documented leveling of the lower arch using metallic implants for reference. Am J Orthod, 1973;63:526-532.

18. Ricketts RM. Bioprogressive therapy as an answer to orthodontic needs. Part I. Am J Orthod, 1976;70:241-268.

19.van Steenbergen E, Burstone CJ, PrahlAndersen B, Aartman IHA. Influence of buccal segment size on prevention of side effects from incisor intrusion. American Journal of
Orthodontics and Dentofacial Orthopedics, 2006;129:658-665.

20.Dake ML, Sinclair PM. A comparison of the Ricketts and Tweed-type arch leveling techniques. Am J Orthod Dentofacial Orthop, 1989; 95:72-78.

21.Parker CD, Nanda RS, Currier GF. Skeletal and dental changes associated with the treatment of deep bite malocclusion. American Journal of Orthodontics and Dentofacial Orthopedics, 1995;107:382-393.

22. Barton KA. Overbite changes in the Begg and edgewise techniques. Am J Orthod, 1972;62:48-55.

23. Upadhyay M, Nanda R. Etiology, Diagnosis and Treatment of Deep Overbite. In: Dolan J (translate eds). R. Nanda SK (eds). Current Therapy in Orthodontics, 1th ed. Missouri, Mosby Elsevier, 2010;186-198.

24. Tosun Y. Sabit Ortodontik Apareylerin Biyomekanik Prensipleri. 1th ed. İzmir, Ege Üniversitesi Basımevi, 1999.

25. Otto RL, Anholm JM, Engel GA. A comparative analysis of intrusion of incisor teeth achieved in adults and children according to facial type. Am J Orthod, 1980;77:437-446.

26.Kinzel J, Aberschek P, Mischak I, Droschl H. Study of the extent of torque, protrusion and intrusion of the incisors in the context of Class II, division 2 treatment in adults. J Orofac Orthop, 2002;63:283-299.

27. Steenbergen Ev, Burstone CJ, PrahlAndersen B, Aartman IHA. The Role of a High Pull Headgear in Counteracting Side Effects from Intrusion of the Maxillary Anterior Segment. Angle Orthod, 2004;74:480-486.

28.Upadhyay M, Nagaraj K, Yadav S, Saxena R. Mini-implants for en masse intrusion of maxillary anterior teeth in a severe Class II division 2 malocclusion. J Orthod, 2008;35:7989. 
29. Amasyalı M, Sağdıç D, Ölmez H, Akın E. Intrusive Effects of the Connecticut Intrusion Arch and the Utility Intrusion Arch. Turkish Journal of Medical Sciences, 2005;407-415.

30. Senisik NE, Turkkahraman H. Treatment effects of intrusion arches and mini-implant systems in deepbite patients. Am J Orthod Dentofacial Orthop, 2012;141:723-733.

31.Sarver DM. Interactions of hard tissues, soft tissues, and growth over time, and their impact on orthodontic diagnosis and treatment planning. Am J Orthod Dentofacial Orthop, 2015;148:380-386.

32. Yeter MY. Diş-doku destekli ve kemik destekli molar distalizasyonu apareylerinin 3 boyutlu olarak karşılaştırılması. Erzurum: Atatürk Üniversitesi, 2012.

33.Kurt E. İskeletsel sınıf III anomaliye sahip bireylerde diş-kemik destekli yüz maskesi tedavisinin kraniofasiyal yapilara etkilerinin konik 1şınlı bilgisayarlı tomografik görüntüleme yöntemiyle incelenmesi. Ortodonti Erzurum: Atatürk Üniversitesi, 2013.

34.Ates FN. Hızlı üst çene genişletmesinin kranio-fasiyal yapılara etkilerinin, konik ışınlı bilgisayarlı tomografi görüntüleme ve üç boyutlu sefalometri yöntemleri ile incelenmesi. Ortodonti Erzurum: Atatürk Üniversitesi, 2012.

35.Houston WJB. The analysis of errors in orthodontic measurements. Am J Orthod Dentofacial Orthop, 1983;382-390.

36. Proffit WR, RP W, Sarver DM. Long Face Problems. In:Proffit WR, RP W, Sarver DM (eds). Contemporary Treatment of Dentofacial Deformiy, St Louis, Mosby, 2003;464-506.

37.Şenışık NE. Derin Kapanışlı Vakaların İmplant ve İntrüzyon Arkları ile Tedavilerinin Karşılaştırılması. Sağlık Bilimleri Enstitüsü Ortodonti Anabilim Dalı. Isparta: T.C. Süleyman Demirel Üniversitesi, 2009.

38. Ohnishi H, Yagi T, Yasuda Y, Takada K. A Mini-Implant for Orthodontic Anchorage in a Deep Overbite Case. Angle Orthod, 2005;75:444-452.

39. Upadhyay M, Yadav S, Patil S. Miniimplant anchorage for en-masse retraction of maxillary anterior teeth: a clinical cephalometric study. Am J Orthod Dentofacial Orthop, 2008;134:803-810.

40.Woods MG. The mechanics of lower incisor intrusion:Experiments in nongrowing baboons. Am J Orthod Dentofacial Orthop, 1988;93:186-195.

\section{Correspondence author at:}

Fatih KAHRAMAN

Department of Orthodontics

Faculty of Dentistry

Osmangazi University

ESKISSEHIR, TURKEY

Phone: 0(533) 6479453

E-mail: dr.fatihkahraman@hotmail.com 